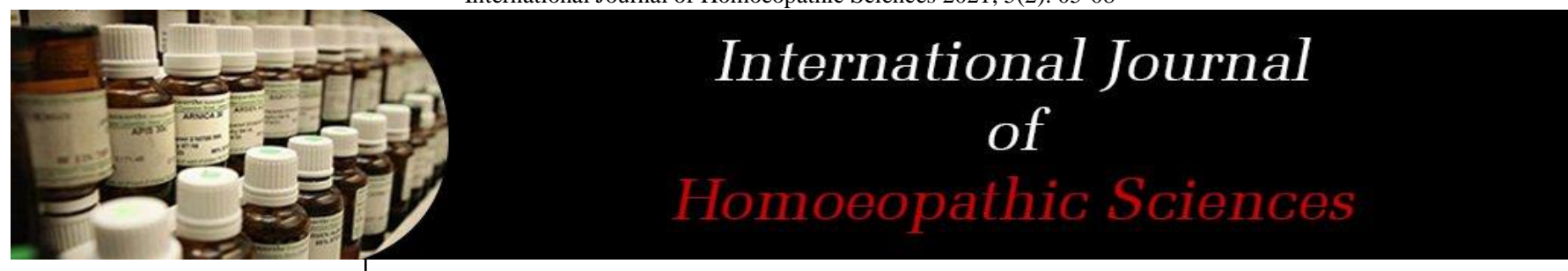

E-ISSN: 2616-4493

P-ISSN: 2616-4485

www.homoeopathicjournal.com

IJHS 2021; 5(2): 05-08

Received: 05-01-2020

Accepted: 08-02-2020

Dr. Priyanka Nagar

MD Scholars, Department of

Practice of Medicine, Dr. MPK

Homoeopathic Medical

College, Hospital and Research

Centre, Jaipur, Rajasthan,

India

Dr. Garima Choudhary

Department of Practice of

Medicine, Dr. MPK

Homoeopathic Medical

College, Hospital and Research

Centre, Jaipur, Rajasthan,

India

Dr. Sonu Mahiya

Department of Practice of

Medicine, Dr. MPK

Homoeopathic Medical

College, Hospital and Research

Centre, Jaipur, Rajasthan,

India

Dr. Nipun Singh Dabi

Department of Practice of

Medicine, Dr. MPK

Homoeopathic Medical

College, Hospital and Research

Centre, Jaipur, Rajasthan,

India

Dr. Dharmendra Kumar Saini Department of Practice of Medicine, Dr. MPK

Homoeopathic Medical College, Hospital and Research Centre, Jaipur, Rajasthan, India

Corresponding Author:

Dr. Priyanka Nagar

MD Scholars, Department of

Practice of Medicine, Dr. MPK

Homoeopathic Medical

College, Hospital and Research

Centre, Jaipur, Rajasthan,

India

\section{Effectiveness of Thuja occidentalis in the treatment of cutaneous horn on eyelid: A case report}

\author{
Dr. Priyanka Nagar, Dr. Garima Choudhary, Dr. Sonu Mahiya, \\ Dr. Nipun Singh Dabi and Dr. Dharmendra Kumar Saini
}

DOI: https://doi.org/10.33545/26164485.2021.v5.i2a.353

\begin{abstract}
Background: A cutaneous horn is a firm, conical, hyperkeratotic epithelial lesion resembling an animal horn. It can vary in size from a few millimeters to several centimeters. They are frequently associated with various benign, premalignant and malignant lesions, and therefore have a clinical significance.

Case summary: A 55 years old male patient reported to Dr. Girendra Pal Homoeopathic Hospital and Research Centre in outpatient department on 26/12/2020 with clinical condition of cutaneous horn presented as a well-defined elevated cutaneous mass of size $2 \mathrm{~cm}$ long and $1 \mathrm{~cm}$ in width with the clinical appearance of an antler (horn) or spike projecting vertically off the skin of left upper eyelid. The patient responded well with Thuja occidentalis with complete recovery within 1 month. Hence, this case emphasizes the importance of Thuja in the treatment of cutaneous horn.
\end{abstract}

Keywords: Cutaneous horn, homoeopathy, Thuja occidentalis

\section{Introduction}

Cutaneous horn (cornu cutaneum) is a term referring to a conical lesion comprising of cohensive keratinized material which visually resembles like a horn of an animal but lacks a bony core ${ }^{[1]}$. A cutaneous horn is a firm, non pigmented, conical keratotic excrescence ${ }^{[2]}$. Having a height that is more than half of the diameter of its base. The lesion is usually evident upon physical examination and can be described as white or yellow exophytic protrusion in the shape of an animal horn. Cutaneous horn are now widely accepted as a reactive cutaneous growth caused by a variety of benign, premalignant or malignant primary processes ${ }^{[3]}$. They mostly occur in sun exposed parts such as face, forearms and dorsum of hands ${ }^{[4]}$.

\section{Etiology}

The etiology of cutaneous horns varies as it is a secondary manifestation of a benign, premalignant or malignant primary disease.

The most common cause of benign cutaneous horns is seborrheic or lichenoid keratosis ${ }^{[5]}$. Other benign causes include infections like human papillomavirus, molluscipoxvirus, chronic irritation, haemagioma ${ }^{[6]}$. Epidermal nevus ${ }^{[7]}$. trichilemmoma, sebaceous adenoma [8]. Actinic keratoses are the most common premalignant primary cause of cutaneous horn, while squamous cell carcinoma is the most common malignant cause ${ }^{[5]}$.

\section{Histopathology}

Histopatholgy of cutaneous horn reveals hyperkeratosis i.e. thickening of the cutaneous stratum corneum and parakeratosis which is the retension of nuclei within the stratum corneum, usually associated with atypical keratinocytes ${ }^{[2]}$.

Various malignancies have been described at the base of cutaneous horns, including cutaneous malignant melanoma, ${ }^{9]}$ meckel-cell carcinoma, ${ }^{[10]}$ sebaceous gland carcinoma, ${ }^{[11,12]}$ Kaposi's sarcoma ${ }^{[13]}$.

\section{Diagnosis}

- The diagnosis is mostly clinical. Patients typically present with a hard, conical projections, most commonly seen over the sun exposed parts of the body like face, eyelids, forearms etc. ${ }^{[14]}$ Absolute height and width can vary from a few millimeters to several centimeters. Giant cutaneous horns can grow upto $25 \mathrm{~cm}$ long ${ }^{[15]}$ 
- The base of these lesions may be seen as flat, nodular or crateriform.

Surgical excision of the horn along with the tumor base allows for histopathological studies of the lesion and related malignancy.

\section{Treatment/Management}

Cutaneous horn can be treated surgically, medically or via laser ablation. Diagnosis of the cutaneous horn, however, must be made after histological assessmemt due to its ability to appear like other condition such as an ectopic nail ${ }^{[16]}$.

\section{Complications}

Apart from presenting as a cosmetic issue, cutaneous horns may also be associated with pain and rapid growth. There is a considerable chance that there could be a premalignant or malignant complication causing the cutaneous horn ${ }^{[3]}$.

\section{Case Report}

A 62 years old male, an agricultural farmer reported to the OPD on 26/12/2020 with a complaint of single eruption clinically presented as a horny eruption on left upper eyelid of size $2 \mathrm{~cm}$ long with $1 \mathrm{~cm}$ width projecting vertically off the skin since 1 month. There was no pain or redness around the eruption.

\section{History of presenting complaint}

Patient was apparently well 3 months back, then he suddenly noticed a growth on left upper eyelid which grew in size rapidly. Patient cauterized the eruption after 1 month of its appearance. Again there was reoccurrence of the same growth at same place after one month of cauterization.

\section{General symptoms}

No uncommon or characteristic general symptoms (mental and physical) present. Patient drinks 3-4 litres of water per day. Appetite is good. Stools and urine are normal. Sound sleep and moderate perspiration according to season and work. Patient is ambithermal.

\section{Past history}

He suffered from PUO in 2011. He had no history of any trauma.

\section{Family history}

Mother and father were not alive. There was no family history of any chronic disorder.

\section{Personal history}

He was a chronic smoker (3-4 bidi/day) for the past 20 years. He had a prolonged history of sun exposure.

\section{Physical examination}

Patient was oriented with time, place and person. There were no signs of pallor, cyanosis, clubbing, icterus and lymphadenopathy. His blood pressure was $128 / 84 \mathrm{~mm}$ of
$\mathrm{Hg}$, pulse 78/min, afebrile, weight about $78 \mathrm{~kg}$. He was tall and well built.

\section{Local examination}

On examination, the lesion was $2 \mathrm{~cm}$ in height and $1 \mathrm{~cm}$ in width present over left upper eyelid. It was non-tender and firm to hard in consistency. He had no other similar eruption over other parts of his body.

\section{Clinical diagnosis: Cutaneous horn}

\section{Case analysis}

In this case, clinical picture was considered for repertorization as no characteristic physical or mental generals were present. This case was presented as one-sided local disease with marked characteristic particular symptom.

\section{Miasmatic analysis of case ${ }^{[17]}$}

Hahnemann has recognized three special forms of miasms, which he designated as psora, sycosis and syphilis. Psora is the beginning of all physical sickness. As this morbid vital process is associated with outer manifestations of some sort of itching skin eruption, it was described as the 'internal itch disease' by Hahnemann.

The sycotic manifestation includes infilteration and over growth of tissue. Warts, moles, keloids, thrown up externally gives us indication that the patient has entered the sycotic defence stage.

The syphilitic has as its hallmark ulceration and destruction of tissue, even to bony tissue. As the case is presented with horny eruption projecting vertically off the skin indicates sycotic manifestation.

\section{Repertorial analysis}

1. According to 'Repertory of the Homoeopathic Materia Medica' by J.T.Kent.

- $\quad$ Eye - Eruptions - lids, on : Ant-t., bry., carb-s., Graph., guaj., Hep., kali-s., mag-m., mez., nat-m., psor., puls., sars., sil., Thuj., rhus-t., sulph.

- Eye - Condylomata - eyelid: Caust., cinnb., nit-ac., suplh., Thuj.

\section{According to 'BBCR' by C.M.Boger}

- $\quad$ Eye - Eyelids - warts: Caus., Thu.

\section{Selection of remedy}

As per the repertorial analysis and miasmatic consideration, Thuja occidentalis was selected in this case.

\section{Justification of selection of Thuja occidentalis}

Its relation to the production of pathological vegetations condylomata, warty excrescences, spongy tumors is very important. The main action of Thuja is on the skin, producing conditions that correspond with Hahnemann's sycotic dyscrasia ${ }^{[18]}$. Horny excrescences, more upon the skin, split open form upon a pedicle and crack around the base ${ }^{[19]}$

Table 1: Treatment and follow-up

\begin{tabular}{|c|c|c|}
\hline Date & Symptoms & Prescription \\
\hline $26 / 12 / 2020$ & $\begin{array}{c}\text { Single horny eruption of size } 2 \mathrm{~cm} \text { long and } 1 \mathrm{~cm} \\
\text { width on left upper } \\
\text { eyelid }\end{array}$ & $\begin{array}{c}\text { Thuja occidentalis 200CH/1dose } \\
\text { advised to take empty stomach } \\
\text { Placebo 30/TDS/15 days }\end{array}$ \\
\hline
\end{tabular}




\begin{tabular}{|c|c|c|}
\hline $11 / 01 / 2021$ & Size of lesion same as before & Placebo 30/TDS/15 days \\
\hline $25 / 01 / 2021$ & Eruption over eyelid shed off & Placebo 30/TDS/15 days \\
\hline $01 / 02 / 2021$ & No relapse of previous eruption & No medicine was prescribed \\
\hline
\end{tabular}

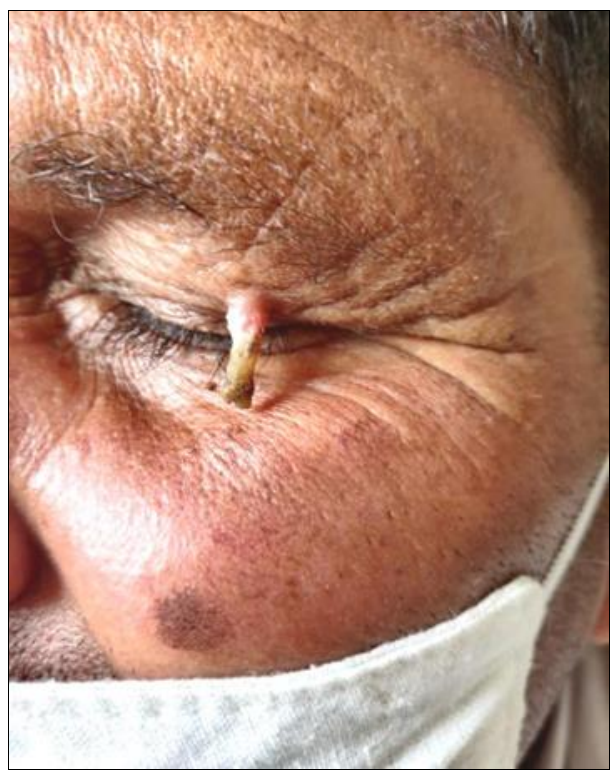

Fig 1: Before treatment

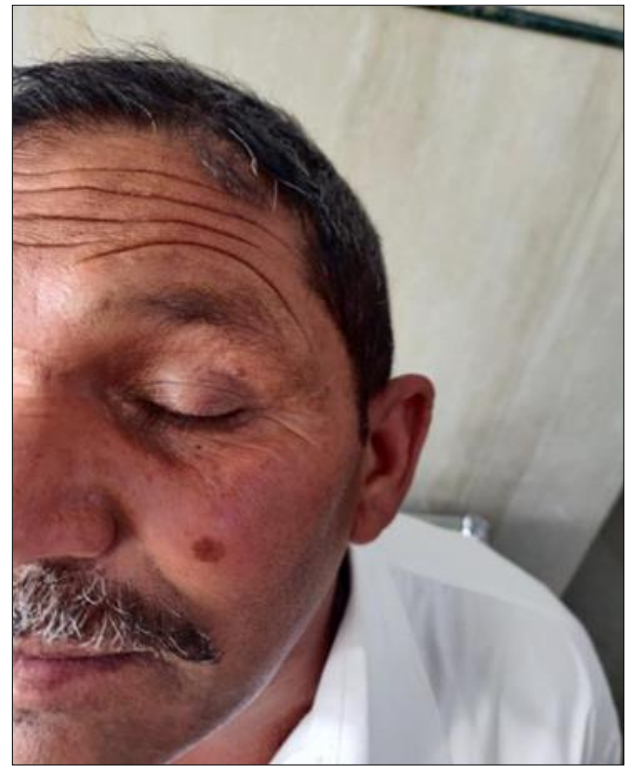

Fig 2: After treatment

\section{Discussion}

Besides the local affection, requiring surgical and mechanical treatment, there are local affections that proceed from an internal morbid state. The medicine selected for such local maladies must therefore be based on the totality of symptoms which includes the local affection as the most guiding symptom of the whole disease. In the case presented here, the patient was presented only with local disease so the prescription was based on particular symptom rather than on general symptoms of the patient ${ }^{[20]}$. As Thuja is a great antisycotic remedy, so the treatment was began with Thuja $200 \mathrm{CH}$. Thuja was used in medium potency because the patient was of old age, which showed a moderate susceptibility of the patient.

Cutaneous horn was resolved within a month after treatment with no reoccurrence till date. This justifies the correct selection of remedy, its potency and repetition.

\section{Conclusion}

The treatment and consequent removal of local affections with corrosive, caustic or by excision leads us into greater difficulties for bringing about complete cure of the patient. Hence, all curative measures should be planned, with reference to the state of the whole system and by means of internal remedies. A gradual disappearance of the local manifestation of disease will surely accompany the restoration of health. The present case brings to light the effectiveness of Thuja in the treatment of cutaneous horn.

\section{Declaration of patient consent}

A written informed consent was taken from the patient. In the form, the patient has given written consent for his clinical information and images to be reported in the journal.

\section{Financial support and sponsorship}

Nil.

\section{Conflicts of interest}

None declared.

\section{References}

1. Cardis MA, Kirkorian AY. Giant Cutaneous Horn Arising in an Epidermal Nevus. Pediatr Dermatol 2017;34(5):e290-e291.

2. Requena L Requena C, Cockerell CJ. Benign epidermal tumors and proliferations. In: Bolognia J, Jorizzo JL, Schaffer JV, eds. Dermatology. 3rd ed. Philadelphia, PA: Elsevier Saunders 2012:1805-6.

3. Thiers BH, Strat N, Snyder AN, Zito PM. Cutaneous Horn. 2021. In: StatPearls [Internet].

4. The curled sebaceous horn. Tanuja BM. Text Book of Medicine. Ramdass MJ. Clin Case Rep. 2015;4:118119.

5. Mantese SA, Diogo PM, Rocha A, Berbert AL, Ferreira AK, Ferreira TC. Cutaneous horn: a retrospective histopathological study of 222 cases. An Bras Dermatol 2010;85(2):157-63. [PubMed]

6. Karthikeyan K. Penile cutaneous horn: An enigmanewer insights and perspectives. Indian $\mathrm{J}$ Sex Transm Dis AIDS. 2015;36(1):26-9. [PubMed]

7. Cardis MA, Kirkorian AY. Giant Cutaneous Horn Arising in an Epidermal Nevus. Pediatr Dermatol 2017;34(5):e290-e291. [PubMed]

8. Ruggiero M, Melli M, Parma B, Bianchini P, Vannucchi S. Isolation of endogenous anticoagulant $\mathrm{N}$ sulfated glycosaminoglycans in human plasma from healthy subjects. Pathophysiol Haemost Thromb 2002;32(1):44-9. [PubMed]

9. Nishida H, Daa T, Kashima $\mathrm{K}$ et al. Cutaneous horn malignant melanoma. Dermatol Reports 2013;5:e3.

10. Schick BA, Tobe JS, Joseph MG et al. Incidental Merkel cell carcinoma in a cutaneous horn: a case report. Dermatol Pract Concept 2015;5:47-50.

11. Jhuang JY, Liao SL, Tsai JH, et al. Extraocular welldifferentiated sebaceous tumors with overlying cutaneous horns: four tumors in three patients. J Cutan Pathol 2014;41:650-6. 
12. Baumüller S, Herwig MC, Mangold E et al. Sebaceous gland carcinoma of the eyelid masquerading as a cutaneous horn in Li-Fraumeni syndrome. $\mathrm{Br} \mathrm{J}$ Ophthalmol 2011;95:1470.

13. Silapunt S, Jordon RE, Piao Y et al. Kaposi sarcoma presenting as a cutaneous horn. J Am Acad Dermatol 2011;64:447-8.

14. Pyne J, Sapkota D, Wong JC. Cutaneous horns: clues to invasive squamous cell carcinoma being present in the horn base. Dermatol Pract Concept 2013;3(2):3-7. [PubMed]

15. Fernandes NF, Sinha S, Lambert WC, Schwartz RA. Cutaneous horn: a potentially malignant entity. Acta Dermatovenerol Alp Pannonica Adriat. 2009;18(4):189-93. [PubMed]

16. Narang T, Kanwar AJ. Ectopic nail with polydactyly. J Am Acad Dermatol 2005;53(6):1092-3. [PubMed]

17. Robert HA. The Principles of Art and Cure by Homoeopathy. New Delhi: B.Jain Publishers (P) Ltd; Reprint ed. 1997.

18. Boericke W. Pocket manual of homoeopathic materia medica and repertory. (51st Impression), B. Jain Publishers (P) Ltd, New Delhi, India, 2011.

19. Kent JT. Lectures on homoeopathic philosophy. B. Jain Publishers (P) Ltd. New Delhi, India, 2011.

20. Sarkar BK. Organon of medicine. Delhi: Birla Publications Pvt. Ltd. ed 10 ${ }^{\text {th }}$ reprint 2009-2010. 